\title{
CYTOTOXICITY OF THREE ROOT CANAL SEALERS ON HUMAN FIBROBLAST CELLS (WI-38) AT DIFFERENT TIMES AND CONCENTRATIONS
}

\author{
Khaled Ali Beshr* and Ramy Abdallah Abdelrahim**
}

\begin{abstract}
Introduction: The aim of the present study was to evaluate the in vitro cytotoxicity of three endodontic sealers (TotalFill BC, Gutta Flow2 and AH Plus) on WI-38 cell line human. As a reference, $\mathrm{AH}$ Plus was compared with the more recent endodontic sealers regarding cell viability of fibroblast cells (WI-38).
\end{abstract}

Methods: Biological testing was carried out in vitro on WI-38 cells. Cell viability assay was performed by using eluates from each endodontic sealer and dispensed to pre-cultured WI-38 cell line. The effect was assessed by MTT cell proliferation assay and ELISA reader after 24 hours and 72 hours of exposure and various concentrations of $(0.5,1,2,4,8,16,32,64,125,250$ and 500mg/ $\mathrm{ml})$. Statistical differences were assessed by analysis of variance and Tukey test $(\mathrm{P}<.05)$.

Results: TotalFill BC, Gutta Flow2 and AH Plus sealer eluates for 24 hours showed no cytotoxic effect, while it was increased by increasing the concentration for 72 hours' measurement. Statistically there is no significant difference among the tested sealer materials; TotalFill BC, Gutta Flow2 and AH Plus.

Conclusions: In the present study TotalFill BC, Gutta Flow2 and AH Plus sealer eluates showed no cytotoxic effects at least in the first 24 hours. But they exhibited moderately or severely cytotoxic activity at 72 hours of measurement at high concentration.

KEYWORDS: Cytotoxicity, Root canal sealer, Fibroblast Cell

\section{INTRODUCTION}

The most important step of endodontic treatment, after cleaning and shaping the root canal system, is three-dimensional filling "obturation" (1). Traditionally; the obturation techniques of root canals depend on filled them with gutta-percha points in combination with endodontic sealers ${ }^{(1,2)}$.
Endodontic sealers act as a lubricant during guttapercha insertion into the radicular canal system, thus permit filling of empty areas where guttapercha was not able to penetrate as in accessory spaces ${ }^{(3)}$. Moreover, sealer prevent the apical and coronal infiltration and the proliferation of microorganisms and promote periradicular tissue repair ${ }^{(4,1)}$.

\footnotetext{
* Lecturer of Endodontics, Faculty of Dentistry, Baniswif University

** Lecturer of Dental Bio-Materials, Faculty of Dentistry, Al-Azhar University
} 
Clinically, sealers are introduced into canals in a fresh, unset state ${ }^{(5)}$. They are designed to be confined within the canal; however, they might be extruded beyond the apical constriction, may come in direct contact with periapical tissues and may affect them ${ }^{(1,6,7)}$.

However, when extruded into the periradicular spaces, sealers may not always be removed by periradicular tissue reaction ${ }^{(8)}$ and may alter tissue repair time ${ }^{(9)}$ and cause different tissue reactions depending on the sealer's composition ${ }^{(10)}$.

Even without extrusion, sealers may release some chemical components to the periapical tissues (11). Thus, root canal sealers should be non-cytotoxic and biocompatible with periapical tissues ${ }^{(12)}$. As a result, in vitro cytotoxic studies of these endodontic sealers are the first step toward an evaluation of their safety ${ }^{(13)}$.

At the present time, the commercially available sealers can be subgroups into five chemically different groups: $\mathrm{ZO} / \mathrm{E}$ cement, $\mathrm{Ca}-\mathrm{OH}$ cement, GIC cement, epoxy resins cement, and Silicate/ based cement ${ }^{(14,15)}$.

AH Plus is an epoxy-resin that characterized by low solubility and disintegration, superlatively flow performance, better adhesion and improved radiopacity ${ }^{(16)}$. AH Plus sealer, however, it produce longstanding dimensional stability, but, it does not produce intimate bond with guttapercha, which is why disagreement remains ${ }^{(17)}$.

Gutta Flow2, an evolution of its predecessor Gutta Flow, is a cold flowable system combining both of gutta-percha powder with average particle size $30 \mu \mathrm{m}$ or less, and polydimethylsiloxane sealer, in an automix syringe. Both Gutta- Flow and GuttaFlow2 are silicone-based endodontic sealers that differ in the form of the silver particles used $^{(18,19)}$.

TotalFill BC Sealer is a bioceramic-based sealer, which recognize for their biocompatibility, bioactivity and antibacterial activity, as well as for their excellent physico-chemical properties ${ }^{(1,5,20)}$.
This study was designed to assess and compare the cytotoxicity of three endodontic sealers TotalFill BC, Gutta Flow2 and AH Plus in contact with (WI38) fibroblast cells over a period of 24 hours and 72 hours and different concentrations. AH Plus, was used as reference material for comparison.

\section{MATERIAL AND METHODS}

\section{Sealer Extracts}

The materials tested were GuttaFlow2/silicone -based sealer (Colten/Whaledent, USA), TotalFill BC Sealer/bioceramic-based sealer (FKG Dentaire SA, La Choux-de-Fonds, Switzerland), and AH Plus/resin-based sealer (Dentsply DeTroy GmbH, Konstanz, Germany).

The sealers were prepared according to the manufacturers' instructions. Dental sealers were weighted under sterile conditions as $0.5 \mathrm{gm}$, and stored in an incubator at $37{ }^{\circ} \mathrm{C}$ for 24 hours to achieve complete setting. Hanks Balanced salt solution (HBSS) as simulating body fluid (Thermo Fisher Scientific, USA) was added to the set sealer for 7 days, to simulate the clinical situation whereby endodontic sealer is present in the apical region of the root and extruded over the apex, a region where body fluids are found ${ }^{(21)}$. The eluates of the different materials were extracted in sterile conditions by using Dulbecco modified Eagle medium (DMEM) culture medium as extraction vehicle. Subsequently, various concentrations of $(0.5,1,2,4,8,16,32,64$, 125,250 and $500 \mathrm{mg} / \mathrm{ml}$ ) of these extraction media were prepared with fresh DMEM medium.

\section{Isolation and Culture of WI-38 cells}

The eluates of the different endodontic sealer materials were extracted in sterile conditions and collected 7 days' post soaking by using cold centrifugation (Jouan-j 22- France) and dispensed to pre-cultured WI-38 cell line human; Caucasian fibroblasts-like fetal lung cell, (Sigma Aldrich, USA) ${ }^{(22,23)}$. 
Treated cells were observed for 3 days and toxicity of different sealer materials was determined at 24 hours and 72 hours. Detached cells were washed out using phosphate-buffer saline (PBS) ${ }^{(21)}$.

\section{Cell Viability Test}

Cell viability and cell proliferation were measured at 24 hours and 72 hours of exposure, with MTT cell proliferation assay (Thermo Fisher Scientific, USA) of $0.5 \mathrm{mg} / \mathrm{ml}$ was dispensed to the rest of live cells for 4 hours at $37{ }^{\circ} \mathrm{C}^{(22,23)}$. The optical density (OD) of developed dissolved MMT - Formazan crystals was read using ELISA reader (Elx.800-Biotek, USA) ${ }^{(21,24)}$.

Cell viability $\%$ was calculated according to the following equation ${ }^{(23,25)}$ :

\section{Statistical Analysis}

Statistical differences between the control and proliferation in the presence of the sealers' extracts were analyzed using the SPSS 17 pack- age (SPSS Inc., Chicago, IL). One-way analysis of variance and the post hoc Tukey test were performed. A $P$ values $<0.05$ were considered statistically significant.

\section{RESULTS}

Cell viability results of TotalFill BC, Gutta Flow2 and $\mathrm{AH}$ Plus sealer eluates are shown in Table 1 and Figure 1. The different sealers eluates were cytotoxic in a concentration-and time-dependent manner. Where, cell viability decreased with increase culture time and concentration of elutes.

At 24 hours; the all sealer reveals non-toxic manner. Although; all tested sealer show reduction of cell viability of about $20 \%$ at high elutes concentration especially at concentration $500 \mathrm{mg} / \mathrm{ml}$.

At 72 hours, cell viability in the presence of the tested endodontic sealers at concentrations of 250 $\mathrm{mg} / \mathrm{ml}$ and $500 \mathrm{mg} / \mathrm{ml}$ markedly decreased but with no significance difference among all tested sealer materials eluates.

All sealers exhibited a similar cell death morphology with apoptosis which cells showed nuclear condensation as shown in Figure 2. There are no statistically significant differences at each tested times 24 hours $(P>0.05)$ and 72 hours $(P>0.05)$, and also at different concentrations of measurement.

TABLE (1) Statistical analysis of cell viability test at 24 hours and 72 hours measurement.

\begin{tabular}{|l|l|l|l|l|}
\hline 24h Measurement & Endodontic Sealer Materials & Mean & SD & P-value \\
\cline { 2 - 4 } & TotalFill BC & 98.89 & 5.05 & \multirow{2}{*}{0.88} \\
\cline { 2 - 4 } & Gutta Flow 2 & 97.91 & 5.49 & \\
\cline { 2 - 4 } & AH plus & 97.74 & 6.1 & \multirow{2}{*}{ P-value } \\
\hline \multirow{2}{*}{ 72h Measurement } & Endodontic Sealer Materials & Mean & SD & \\
\cline { 2 - 4 } & TotalFill BC & 74.88 & 34.28 & \\
\cline { 2 - 4 } & Gutta Flow 2 & 83.38 & 29.91 & \\
\cline { 2 - 4 } & AH plus & 78.92 & 33.63 & \\
\hline
\end{tabular}




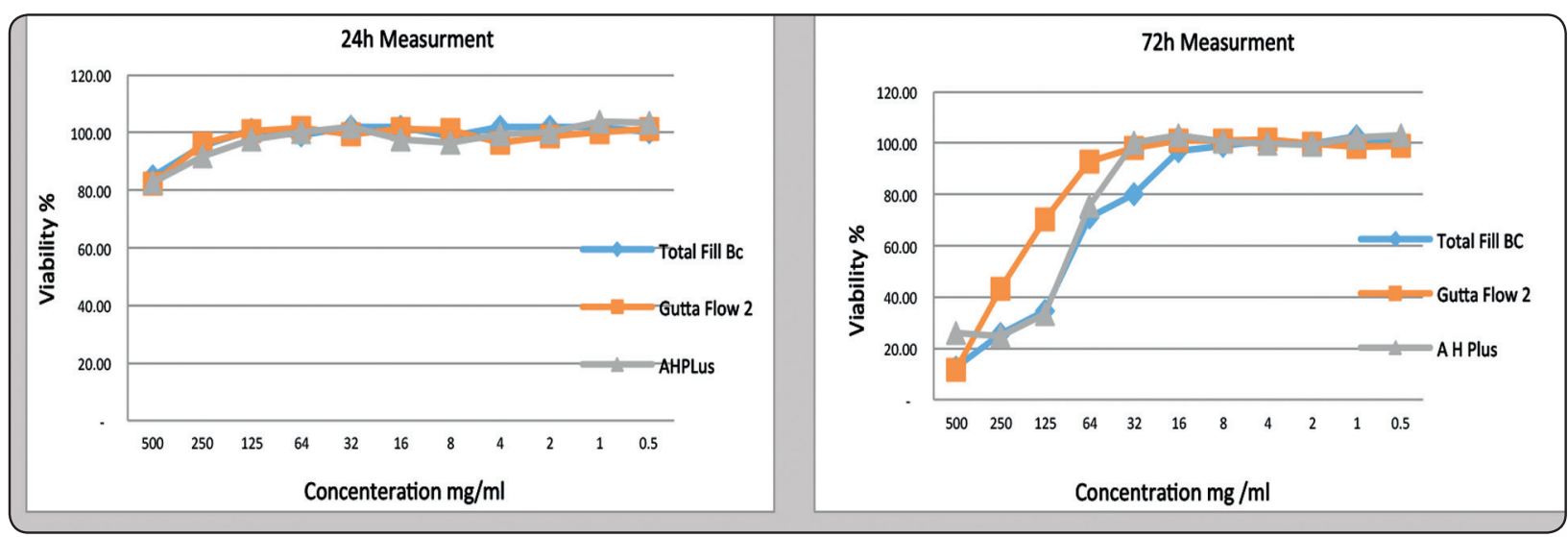

Fig. (1) Cell viability that determined by using the MTT assay; at 24 hours and 72 hours.

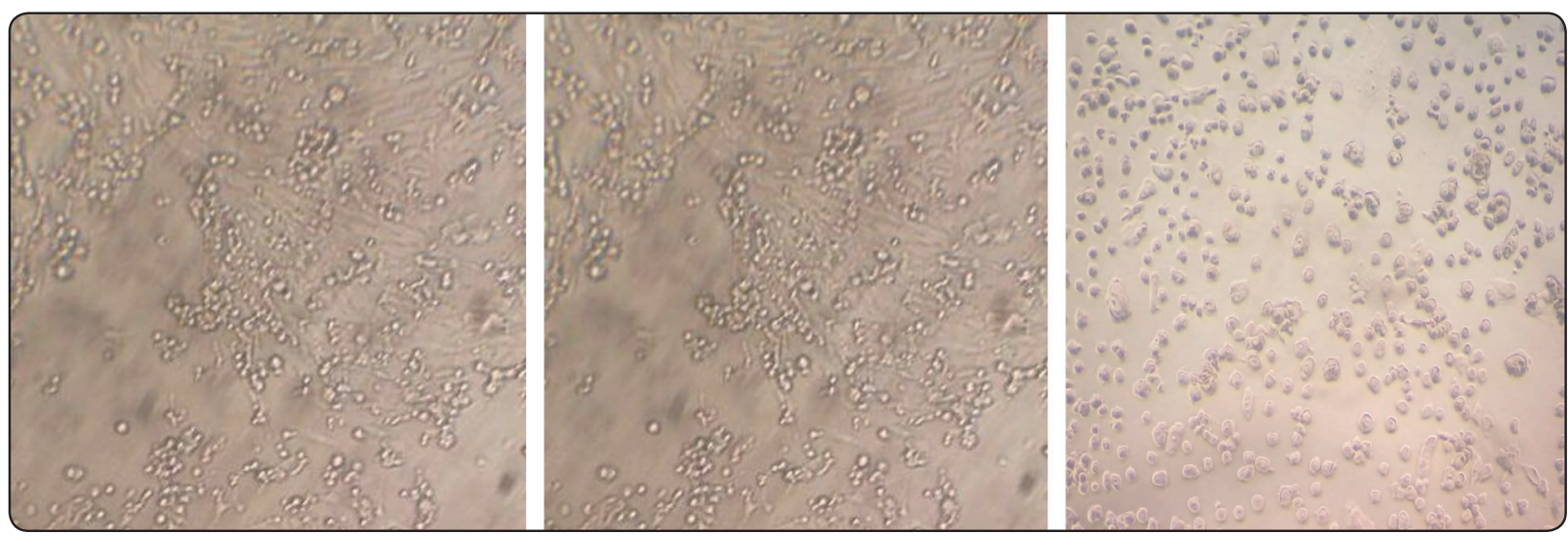

TotalFill BC

Gutta Flow 2

AH Plus

Fig. (2) Image of cell viability test of all tested groups at 72 hours (10X magnification)

\section{DISCUSSION}

Root canal sealers should be biocompatible because they might become in an intimate contact to the soft preapical tissues due to their accidently extrusion thought the apical foramen or at least them elutes ${ }^{(26,27)}$. The endodontic sealer or elutes, when extruded out of the root canal could induce cytotoxic damage to tissue and may have different level of cytotoxicity over a period of 24 hours or 72 hours ${ }^{(26,27)}$. So, it is important to evaluate the cytotoxicity of endodontic sealers materials and them elutes after setting over different periods and concentrations because they probably change their cytotoxicity due to diffusion of toxic components resulting from the decomposition of sealers components ${ }^{(1,5,26)}$.
Using human primary cells especially fibroblast cell in studies that assess the cytotoxicity of endodontic materials and them elutes are common ${ }^{(1,21)}$. Moreover, fibroblasts are the major constituents of connective tissue, the predominant cell type of periodontal ligament, and are the most important collagen producers in this tissue ${ }^{(28)}$. For these reasons, WI-38 was used in the present study.

Also, in vitro cell testing offers some information regarding the biocompatibility of relatively new endodontic sealers like TotalFill BC and Gutta Flow 2 in comparison with currently used ones as $\mathrm{AH}$ Plus, because AH Plus is one of the most widely evaluated sealer ${ }^{(1,21,26)}$. 
Cell viability and cytotoxicity testing was performed as direct method with direct contact of the endodontic sealer material to the tested extracted cell, that, may give speculated results (26). But to simulate the most common clinical scenario. It is well known, that there is no direct contact between the endodontic sealer materials and preapical tissues in most clinical cases ${ }^{(26,29)}$. The most accepted clinical scenario is; the sealer degrade due to the penetration of the tissue fluid into the root canal system and degraded component may leached out to the preapical tissues, and, generate local inflammatory response ${ }^{(26,29,30)}$.

After setting, TotalFill BC, Gutta Flow2 and AH Plus Sealers have no cytotoxic effect at 24 hours' measurement and at different sealer elutes concentrations after setting ${ }^{(26,27,31)}$, this, may be due to the tested sealer materials showed little or no ability to release ions after setting and also it is not in direct contact with cell culture ${ }^{(31,32)}$. Although; all tested sealer show cytotoxic effects, lead to a reduction of cell viability of about $20 \%$ at high elutes concentration as shown in Figure 1, which meaning the cytotoxicity of the material is augmented with increase their concentration ${ }^{(33,34)}$.

The increased cytotoxic effect of the Gutta Flow2 sealer at 72 hours may be due to it contain some extraadditives as Guttapercha powder and preservative of silver in micron size. Silver powder relative toxicity reported in some studies, and Guttapercha powder also can produce tissue irritation ${ }^{(35-37)}$. The TotalFill BC is a bioceramic material showed a lower cytotoxicity may be due to the release of some ions especially at high concentration ${ }^{(38)}$. Also, AH Plus was cytotoxic in a concentration-dependent manner. This might be caused by the minimum release of formaldehyde from amines added to accelerate the epoxy polymerization ${ }^{(39)}$.

The cytotoxicity of sealer depends on the solubility of the sealers. For instance, AH Plus is significantly less soluble than the here tested sealers TotalFill BC, Gutta Flow2. That can explain why no significant difference in cytotoxicity among the all tested sealer because, the set AH Plus material has very low degree of solubility ${ }^{(26,40-42)}$.

\section{CONCLUSIONS}

Within the limitations of this in vitro study, the increase in sealers elutes concentration and time may be critical factor in cytotoxicity of endodontic sealer materials. Also, TotalFill BC, Gutta Flow2 and $\mathrm{AH}$ Plus sealer eluates showed no cytotoxic effects at least in the first 24 hours. But they exhibited moderately or severely cytotoxic activity at 72 hours of measurement at high concentration.

\section{REFERENCES}

1. Poggio C, Riva P, Chiesa M, Colombo M, Pietrocola G. Comparative cytotoxicity evaluation of eight root canal sealers. J Clin Exp Dent. 2017; 9 (4): e574-8.

2. Collins J, Walker MP, Kulild J, Lee C. A comparison of three gutta-percha obturation techniques to replicate canal irregularities. JEO 2006; 32:762-5.

3. De-Deu G, Brandão MC, Fidel RAS, Fidel SR. The sealing ability of Gutta FlowTM in oval-shaped canals: an ex vivo study using polymicrobial leakage model. International Endodontic Journal. 2007; 40 (10), 794-799.

4. Schilder H. Filling root canals in three dimensions. JEO. 2006; 32: 281-90.

5. Alsubait SA, Al Ajlan R, Mitwalli H, Aburaisi N, Mah$\operatorname{mood}$ A, Muthurangan M, et al. Cytotoxicity of Different Concentrations of Three Root Canal Sealers on Human Mesenchymal Stem Cells. Biomolec. 2018; (8):68: 2-7.

6. Peng L, Ye L, Tan H, Zaho X. Outcome of root canal obturation by warm gutta-percha versus cold lateral condensation: a meta-analysis. JEO. 2007; 33:106-9.

7. Camilleri J. Sealers and warm gutta-percha obturation techniques. JEO. 2015 ;41: 72-8.

8. Ricucci D, Roc as IN, Alves FR, Loghin S, Siqueira JF Jr. Apically extruded sealers: fate and influence on treatment outcome. JEO. 2016; 42:243-9.

9. Ng YL, Mann V, Gulabivala K. A prospective study of the factors affecting outcomes of non-surgical root canal treatment: part 2- tooth survival. Int Endod J. 2011;44: 610-25.

10. Bernath M, Szabo J. Tissue reaction initiated by different sealers. Int Endod J. 2003; 36:256-61.

11. Huang TH, Ding SJ, Hsu TZ, Lee ZD, Kao CT. Root canal sealers induce cytotoxicity and necrosis. J Mater Sci Mater Med. 2004, 15, 767-71.

12. Torabinejad M, Hong CU, McDonald F, Pitt Ford TR. Physical and chemical properties of a new root-end lining material. JEO 1995; 21:349-53. 
13. Peters OA. Research that matters: biocompatibility and cytotoxicity screening. Int Endod J 2013; 46:195-7.

14. Orstavik, D. Materials used for root canal obturation: technical, biological and clinical testing. Endod Topi. 2005; 12(1), 25-38.

15. Lee K, Williams MC, Camps JJ, Pashley DH. Adhesion of Endodontic Sealers to Dentin and Gutta-Percha. JEO. 2002; 28(10), 684-8.

16. Nunes VH, Silva RG, Alfredo E, Sousa-Neto MD, SilvaSousa YTC. Adhesion of Epiphany and AH Plus Sealers to Human Root Dentin Treated with Different Solutions. Brazil Dent J. 2008; 19(1), 46-50.

17. Bouillaguet S, Shaw L, Barthelemy J, Krejci I, Wataha JC. Long-term sealing ability of Pulp Canal Sealer, AH-Plus, GuttaFlow and Epiphany. Int Endod J. 2008; 41(3), 219-26.

18. Bouillaguet S, Wataha JC, Tay FR, et al. Initial in vitro biological response to contemporary endodontic sealers. JEO. 2006; 32:989-92.

19. Accardo C, Himel VT, Lallier TE. A novel GuttaFlow sealer supports cell survival and attachment. JEO. 2014; 40:23-4.

20. Debelian G, Trope M. The use of premixed bioceramic materials in endodontics. J Itali Endod 2016; 30:70-80.

21. Collado-Gonzalez M, Tomas-Catala C J, Onate-Sanchez R E, Moraleda J M, Rodriguez-Lozano F J. Cytotoxicity of GuttaFlow Bioseal, GuttaFlow2, MTA Fillapex, and AH Plus on Human Periodontal Ligament Stem Cells. JOE. 2017; 43(5): 816-22.

22. van Meerloo J, Kasper G J, Cloos J. Cell sensitivity assays: The MTT assay. Methods Mol Biol. 2011; 731: 237-45.

23. Senthilraja $P$, Kathiresan K. In vitro cytotoxicity MTT assay in Vero, Hep G2 and MCF-7 cell lines study of MARINE yeast. J Appl Pharmac Sci. 2015; 5 (03): 080-4.

24. Patravale V, Dandekar P, Gain R. Nanotoxicology: evaluating toxicity potential of drug-nanoparticles. Nanopartic Drug Deliv. 2012; 123-55.

25. Vouzara T, Dimosiari G, Koulaouzidou EA, Economides N. Cytotoxicity of a New Calcium Silicate Endodontic Sealer. JOE. 2018;44 (5): 849-52.

26. Jung S, Sielker S, Hanisch MR, Libricht V, Schafer E, Dammaschke T. Cytotoxic effects of four different root canal sealers on human osteoblasts. PLoS ONE. 2018; 13(3): 1-14.

27. Silva EJ, Santos CC, Zaia AA. Long-term cytotoxic effects of con- temporary root canal sealers. J Appl Oral Sci. $2013 ; 21: 43-7$.

28. Silva EJ, Neves AA, De-Deus G, Accorsi-Mendonca T, Moraes AP, Valentim RM, Moreira EJ. Cytotoxicity and gelatinolytic activity of a new silicon-based endodontic sealer. J Appl Biomater Funct Mater 2015;13: e376-80.

29. Geurtsen W. Biocompatibility of root canal filling materials. Aust Endod J. 2001; 27: 12-21.

30. Braga JM, Oliveira RR, de Castro Mantins R, Vieira LQ, Sobrinho AP. Assessment of the cytotoxicity of a mineral trioxide aggregate-based sealer with respect to macrophage activity. Dent Traumatol. 2015; 31: 390-5.

31. Zhou H-M, Du T-F, Shen Y, Wang Z-J, Zheng Y-F, Haapasalo M. In vitro cytotoxicity of calcium silicate- containing endodontic sealers. JEO. 2015; 41: 56-61.

32. Bin CV, Valera MC, Camargo SE, Rabelo SB, Silva GO, Balducci I, Camarago CH. Cytotoxicity and genotoxicity of root canal sealers based on mineral trioxide aggregate. JEO. 2012; 38:495-500.

33. Guven EP, Yalvac, ME, Kayahan MB, Sunay H, Sahin F, Bayirli G. Human tooth germ stem cell response to calcium-silicate based endodontic cements. J Appl Oral Sci 2013; 21:35-7.

34. Camps J. Cytotoxicity Testing of Endodontic Sealers: A New Method. JEO. 2003; 29(9), 583-6.

35. Causa F, Netti PA, Ambrosio L, Ciapetti G, Baldini N, Pagani S, Martini D, Giunti A. Poly $\varepsilon$-caprolactone/hydroxyapatite composites for bone regeneration: in vitro characterization and human osteoblast response. J Biomater Rese. Part A. 2006; 76(1), 151-62.

36. Merdad K, Pascon AE, Kulkarni G, Santerre P, Friedman S. Short-term cytotoxicity assessment of components of the Epiphany resin-percha obturation system by indirect and direct contact millipore filter assay. JEO. 2007; 33(1), 24-7.

37. Kayaoglu G, Erten H, Alacam T, Orstavik D. Short-term antibacterial activity of root canal sealers towards Enterococcus faecalis. Int Endod J. 2005; 38(7), 483-8.

38. Alanezi AZ, Jiang J, Safavi KE, Spangberg LS, Zhu Q. Cytotoxicity evaluation of EndoSequence root repair material. Oral Surg Oral Med Oral Pathol Oral Radiol Endod. 2010;109: e122-5.

39. Cohen, B.I.; Pagnillo, M.K.; Musikant, B.L.; Deutsch, A.S. Formaldehyde evaluation from endodontic materials. Oral Health 1998, 88, 37-39.

40. Costa F, Sousa Gomes P, Fernandes MH. Osteogenic and angiogenic response to calcium silicate- based endodontic sealers. JEO. 2016; 42: 113-9.

41. Schafer E, Zandbiglari T. Solubility of root canal sealers in water and artificial saliva. Int Endod J. 2003; 36: 660-9.

42. Schafer E, Bering N, Burklein S. Selected physicochemical properties of AH-Plus, EndoREZ and Real- Seal SE root canal sealers. Odontol. 2015;103: 61-5. 